\title{
Receptor-specific Induction of Insulin-like Growth Factor I in Human Monocytes by Advanced Glycosylation End Product-modified Proteins
}

\author{
Martina Kirstein, * Christopher Aston, * Raymond Hintz" and Helen Vlassara * \\ * Laboratory of Medical Biochemistry, The Rockefeller University, New York 10021; ${ }^{\ddagger}$ Sheikh Rashid Diabetes Unit, Radcliffe Infirmary, \\ Oxford OX2 6 HE England; and ${ }^{\S}$ Department of Pediatrics, Stanford University, Stanford, California 94305
}

\begin{abstract}
Normal tissue homeostasis requires a finely balanced interaction between phagocytic scavenger cells (such as monocytes and macrophages) that degrade senescent material and mesenchymal cells (such as fibroblasts and smooth muscle cells), which proliferate and lay down new extracellular matrix. Macrophages and monocytes express specific surface receptors for advanced glycosylation end products (AGEs), which are covalently attached adducts resulting from a series of spontaneous nonenzymatic reactions of glucose with tissue proteins. Receptor-mediated uptake of AGE-modified proteins induces human monocytes to synthesize and release cytokines (TNF and IL1), which are thought to contribute to normal tissue remodeling by mechanisms not entirely understood. We now report that AGEs also induce human monocytes to generate the potent progression growth factor insulin-like growth factor I (IGF-I), known to stimulate proliferation of mesenchymal cells. After in vitro stimulation with AGE-modified proteins, normal human blood monocytes express IGF-IA mRNA leading to the secretion of IGF-IA prohormone. The signal for IGF-IA mRNA induction seems to be initiated via the monocyte AGE-receptor, and to be propagated in an autocrine fashion via either IL-1 $\beta$ or PDGF. These data introduce a novel regulatory system for IGF-I, with broad in vivo relevance, and provide an essential link to the chain of events leading from the spontaneously formed tissue AGEs, hypothesized to act as markers of protein senescence, to their replacement and to tissue remodeling by the locally controlled induction of growth factors. (J. Clin. Invest. 1992. 90:439-446.) Key words: glycosylated fibronectin • interleukin 1 • platelet-derived growth factor • tissue remodeling • tumor necrosis factor
\end{abstract}

\section{Introduction}

Macrophages and monocytes are not only essential in the host response to various invasive stimuli, but also play an important role in normal tissue turnover, and aseptic wound healing and repair $(1,2)$. An important element of these complex responses is the coordinated secretion of a variety of mitogenic factors and cytokines to act locally in both an autocrine and paracrine manner.

Dr. Vlassara's present address is The Picower Institute for Medical Research, 350 Community Drive, Manhasset, NY 11030.

Address reprint requests to Dr. Vlassara.

Received for publication 22 July 1991 and in revised form $30 \mathrm{De}$ cember 1991.

J. Clin. Invest.

(C) The American Society for Clinical Investigation, Inc.

0021-9738/92/08/0439/08 $\$ 2.00$

Volume 90, August 1992, 439-446
Recently, it has become apparent that growth factors and cytokines which are largely generated in response to exogenous stimuli are also elicited in response to the in vivo nonenzymatic modification of tissue components by glucose $(3,4)$. Advanced glycosylation end products (AGEs), ${ }^{1}$ the late rearrangement products of these glucose-protein reactions are irreversible cross-linking adducts which accumulate on proteins in vivo as a function of protein half-life, chronological age, and ambient glucose levels $(5,6)$. Excessive accumulation of AGE adducts on aging and diabetic tissues is thought to lead to irreversible tissue damage, in part by widespread protein crosslinking and protein trapping (5). A novel system of membrane-associated receptors, comprising at least a 90- and a 60$\mathrm{kD}$ protein specific for the ingestion and elimination of proteins modified by AGEs has been identified on both murine peritoneal macrophages and human monocytes $(7,8)$. In addition, the interaction of AGE-modified proteins with AGE receptors triggers the synthesis and release of cytokines, in particular interleukin-1 $\beta$ (IL-1 $\beta$ ) and tumor necrosis factor- $\alpha$ (TNF$\alpha)$ (3). In that each of these AGE-induced mediators can promote growth responses in various cells, it was proposed that such responses may be central in normal tissue remodeling, in the delivering of signals to nearby mesenchymal cells to replace senescent tissue with new matrix and cellular components. This second limb of the dual-effector functions of the monocyte AGE-receptor system, i.e., the initiation of tissue repair processes, is further assisted by the AGE-induced secretion of platelet-derived growth factor (PDGF), a competence factor for mesenchymal cells (9). The final stimulus for proliferation had not been identified, however.

It has been proposed that once cells, such as fibroblasts and smooth muscle cells, are rendered competent, proliferation can in turn be stimulated by progression-type growth factors such as insulin-like growth factor I (IGF-I) $(9,10)$. IGF-I belongs to the somatomedin family of peptides, which are structurally homologous to proinsulin $(10,11)$, and interact with specific surface receptors on various target cells. Several different forms of IGF-I have been identified. Mature liver IGF-I with an $M_{\mathrm{r}}$ of $7.6 \mathrm{kD}$ is secreted into the circulation (hence the plasma form of IGF-I), where it is associated with a binding protein complex of $\sim 150 \mathrm{kD}$ (12-14). Cultured smooth muscle cells, fibroblasts, and activated alveolar macrophages have all been shown to secrete IGF-I (15-17), and these "tissue-type" somatomedin-like peptides have molecular masses approximately threefold greater (21-25 kD) than the plasma form of IGF-I. Macrophages, isolated from healing wound sites have been shown to produce IGF-I mRNA ( 1). Thus, although activated tissue macrophages are recognized as capable of IGF-I synthesis, circulating monocytes have not been noted to do so.

1. Abbreviations used in this paper: AGE, advanced glycosylation end product; IGF-I, insulin-like growth factor I; PDGF, platelet-derived growth factor; TNF, tumor necrosis factor. 
The present studies reveal that IGF-I mRNA and prohormone are induced in human monocytes after stimulation by AGE-modified proteins, but not by lipopolysaccharide (LPS) or interferon- $\tau$ (IFN- $\tau$ ). The induction of IGF-I is mediated via the monocyte AGE-receptor system and appears to depend on IL-I $\beta$ and PDGF protein secretion. These data strongly support the notion that the natural formation of AGE-proteins in tissues may contribute to the regulation of tissue remodeling through the induction first of "inflammatory" cytokines, then of competence, and ultimately of progression factors, all of which may cooperate closely to coordinate the removal and replacement of molecular and cellular tissue components.

\section{Methods}

Cell preparations, treatments, and RNA extraction. Human peripheral blood monocytes were isolated from fresh blood of healthy volunteers using Ficoll-Hypaque and Percoll gradients $(18,19)$. Cells were suspended in RPMI medium (Mediatech, Inc., Herndon, VA) containing $20 \%$ fetal bovine serum (FBS) (HyClone Laboratories, Inc., Logan, UT) and seeded into six-well tissue culture plates (Flow Laboratories, Inc., McLean, VA). $1 \mathrm{~h}$ after seeding, the nonadhering cells were washed with PBS and adhering monocytes were incubated with either AGE-BSA, BSA, LPS (Difco Laboratories, Inc., Detroit, MI), human IFN- $\tau$ (Amgen, Inc., Thousand Oaks, CA), human IL-1 $\beta$ (Genzyme Corp., Boston, MA), human TNF (Chiron Corp., Emeryville, CA), or human PDGF from platelets (Collaborative Research, Inc., Bedford, MA). For specific experiments monocytes were incubated with AGEBSA in the presence of $100 \mu \mathrm{g} / \mathrm{ml}$ anti-IL- $1 \beta$ antibody, $100 \mu \mathrm{g} / \mathrm{ml}$ anti-TNF antibody (both from Genzyme Corp.) or $50 \mu \mathrm{g} / \mathrm{ml}$ anti-platelet PGDF antibody (Collaborative Research, Inc.). RNA was extracted by a modified guanidinium isothiocyanate method (RNAzol TM, Cinna/ Biotecx, Friendswood, TX). In other experiments, monocytes were incubated for $30 \mathrm{~min}$ at $4^{\circ} \mathrm{C}$ with $20 \mu \mathrm{g} / \mathrm{ml}$ avian anti-60 $\mathrm{kD}$ or anti-90 $\mathrm{kD}$ anti-AGE receptor antibodies raised against the

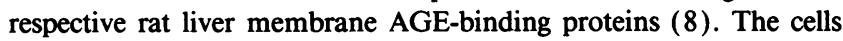
were transferred to $37^{\circ} \mathrm{C}$ and $150 \mu \mathrm{g} / \mathrm{ml} \mathrm{AGE-BSA,} \mathrm{and} 20 \mu \mathrm{g} / \mathrm{ml}$ anti-AGE receptor antibodies were added. For the ensuing $6 \mathrm{~h}$ more antibody was added hourly. The cultures were then washed and allowed to incubate in medium containing $20 \%$ FBS for $18 \mathrm{~h}$, at which point total cellular RNA was extracted as described above.

Preparation of AGE-modified bovine serum albumin. AGE-BSA was prepared by incubating BSA (Fraction V, Boehringer Mannheim, Indianapolis, IN) in phosphate-buffered saline (PBS) (150 mM, pH 7.4) with $50 \mathrm{mM}$ glucose-6-phosphate at $37^{\circ} \mathrm{C}$ for $6 \mathrm{wk}$ in the presence of protease inhibitors ( $1.5 \mathrm{nM}$ phenylmethylsulfonyl fluoride [PMSF] and $1 \mathrm{mM}$ ethelenediaminetetraacetic acid [EDTA] and antibiotics [100 $\mu \mathrm{g} / \mathrm{ml}$ penicillin and $40 \mu \mathrm{g} / \mathrm{ml}$ gentamicin]) as previously described (20). Control BSA was incubated under the same conditions without glucose-6-phosphate. Endotoxin content in each sample was measured by the Limulus amoebocyte lysate assay (E-Toxate, Sigma Chemical Co., St. Louis, MO) and found to be below detectable levels $(<0.2 \mathrm{ng} / \mathrm{ml})$. AGE-specific fluorescence was determined at $450 \mathrm{~nm}$ upon excitation at $390 \mathrm{~nm}$ using an LS-3B fluorescence spectrometer (Perkin-Elmer Corp., Norwalk, CT) and by an AGE-specific radioreceptor assay (20a). AGE-BSA contained 45 AGE-U/mg protein and native BSA 0.3 AGE-U/mg protein.

Preparation of fibronectin-coated tissue culture plates. Human fibronectin (Collaborative Research, Inc.) was incubated with $50 \mathrm{mM}$ G-6-P at $37^{\circ} \mathrm{C}$ for $6 \mathrm{wk}$ as described above for BSA, as were parallel preparations incubated in the absence of sugar, and then plated at 10 $\mu \mathrm{g} / \mathrm{ml}$ onto six-well tissue culture plates. The plates were allowed to dry overnight and gently washed three times with PBS, before freshly isolated monocytes were allowed to adhere. Attachment of AGE-modified or native fibronectin to the tissue culture plates was monitored as de- scribed by Jones et al. (21). After the wells were washed as described above, $300 \mu \mathrm{l}$ of $2 \mathrm{~N} \mathrm{NaOH}$ was added to each well and incubated overnight at $37^{\circ} \mathrm{C}$ in a humid environment in order to dissolve the matrix. The amount of protein on the dish was determined by the method of Lowry et al. (22), while AGE-specific fluorescence was determined as for AGE-BSA. AGE-fibronectin contained $38 \mathrm{AGE}-\mathrm{U} / \mathrm{mg}$ and native fibronectin $1.2 \mathrm{AGE}-\mathrm{U} / \mathrm{mg}$; as determined by radio receptor assay (20a). Measurements indicated that $\sim 70 \%$ of the unmodified and the glucose-modified fibronectin adhered to the plates. Quantitation of the protein by absorbance measurements at $280 \mathrm{~nm}$ gave similar results.

Oligonucleotides used for amplification. Oligonucleotides were synthesized by Oligos Etc. Inc., Guilford, CT. All the primers were RNAspecific primers. Where possible the primers were selected so that each pair flanked an intron. The region between the primers contained at least two restriction enzyme sites. The IGF-I primers included the IGFIA sequence from base 2395 to base 3973 , as numbered by Rotwein et al. (23). This region spans intron 3 and the predicted length of the IGF-I amplification product is 263 bases. The human $\beta$-actin primers included the sequence from position 3076 to 3425 , as numbered by Hanukoglu et al. (24). The predicted length of the polymerase chain reaction (PCR) amplification product is $349 \mathrm{bp}$. The IL-1 $\beta$ primers included the human IL- $1 \beta$ sequence from base 547 to 819 , as numbered by March et al. (25). The predicted length of the amplification product is 272 bases. The TNF primers included the human TNF sequence from base 460 to 765 as described by Wang et al. (26) and the predicted length of the amplification product is 305 bases.

Amplification method. In most cases, distinct sets of cells were exposed to each individual treatment; then separate aliquots of total RNA from each set of cells were reverse-transcribed into cDNA and run through the PCR. In some experiments, however, when cells were treated identically and had to be probed with different primers, the same cDNA aliquots were used and subjected to the PCR with each primer as described. RNA was reverse-transcribed into cDNA by incubating $1 \mu \mathrm{g}$ of total cellular RNA with $50 \mu \mathrm{l}$ of $1 \times$ PCR buffer (Bethesda Research Laboratories). $1 \mu \mathrm{g}$ of BSA per $\mu 1,0.5 \mathrm{mM}$ dNTP, 250 $\mu \mathrm{g} / \mathrm{ml}$ oligo(dT) $)^{12-18}$ and $200 \mathrm{U}$ of Bethesda Research Laboratories Moloney murine leukemia virus reverse transcriptase at $37^{\circ} \mathrm{C}$ for 60 min. PCR was performed at a final concentration of $1 \times$ PCR buffer/ $50 \mu \mathrm{M}$ dNTPs $/ 1 \mu \mathrm{M}$ each 5 ' and 3 ' primers / $2.5 \mathrm{U}$ of thermostable Taq polymerase (Perkin-Elmer Cetus, Norwalk, CT) and $5 \mu$ l cDNA template in a total volume of $100 \mu \mathrm{l}$. The mixture was overlaid with mineral oil and then amplified with a thermal cycler (MJ Research, Watertown, MA). The amplification profile involved denaturation at $92^{\circ} \mathrm{C}$ for $1 \mathrm{~min}$, primer annealing at $55^{\circ} \mathrm{C}$ for $1 \mathrm{~min}$, and extension at $72^{\circ} \mathrm{C}$ for $1 \mathrm{~min}$. To ensure that equal amounts of reverse-transcribed RNA were applied to the PCR reaction, the parallel expression of $\beta$-actin mRNA was tested at 25 or 30 cycles. The amounts of $\beta$-actin mRNA were comparable in all treatments.

Amplification analysis. $10 \mu \mathrm{l}$ of each PCR reaction mixture was electrophoresed in 2\% agarose gels in Tris borate/EDTA buffer. Molecular weight markers ( 123 bp ladder, Bethesda Research Laboratories) were run with each gel. Gels were stained with ethidium bromide and photographed under UV light. For selected experiments the photographic negatives were scanned in a densitometer.

Immunoprecipitation of IGF-I. $1 \times 10^{7}$ Ficoll-purified human monocytes were seeded per well in RPMI containing $20 \%$ dialyzed fetal calf serum (FCS). After 90 min, nonadherent cells were washed away with methionine- and glutamine-free RPMI. The resulting adherent monocytes were incubated for $24 \mathrm{~h}$ in $1 \mathrm{ml}$ methionine-free RPMI, 20\% FCS, 0.5 mCi Tran ${ }^{35}$ S-label (ICN Biomedicals Inc., Costa Mesa, CA ) and either BSA $(150 \mu \mathrm{g} / \mathrm{ml})$, AGE-BSA $(150 \mu \mathrm{g} / \mathrm{ml})$, zymosan A (yeast extract consisted of protein-carbohydrate complexes [150 $\mu \mathrm{g}$ / ml], Sigma Chemical Co.), or with medium alone (control). The medium was then spun to remove cellular material, the supernatants were saved and a mixture of protease inhibitors containing leupeptin, aprotinin, and PMSF was added and immunoprecipitation was performed as described below. Rabbit polyclonal anti-human IGF-I antibody, 
provided by Drs. Underwood and Van Wyk of the University of North Carolina and distributed by the National Hormone and Pituitary Program (UBK487) (27) was added to the supernatants at a concentration of 1:5,000 of the provided stock. The solutions were rocked for $24 \mathrm{~h}$ at $4^{\circ} \mathrm{C}$ and were then spun to remove aggregated material. $30 \mu \mathrm{l}$ of protein A Sepharose beads with $0.02 \% \mathrm{NaN}_{3}$ were added to the supernatants to precipitate antibody and radiolabeled ligand and the solutions were incubated for $12 \mathrm{~h}$ at $4^{\circ} \mathrm{C}$ with continuous shaking. The protein $\mathrm{A}$ beads were washed three times each in the following buffers: $0.1 \%$ Triton X-100/0.02\% SDS/ 50 mM Hepes; $1.0 \%$ Triton X-100/0.2\% SDS, $50 \mathrm{mM}$ Hepes; $0.1 \%$ Triton X-100/0.02\% SDS/50 mM Hepes $/ 0.4 \mathrm{M}$ $\mathrm{NaCl}$; and finally PBS. The beads were subsequently washed in SDSPAGE sample buffer, boiled and the supernatants were run on a gradient SDS-polyacrylamide gel (10-18\%) in the presence of $\beta$-mercaptoethanol. Recombinant human IGF-I (receptor grade, Collaborative Research, Inc.) labeled with ${ }^{125} \mathrm{I}$, using the Bolton Hunter reagent kit (ICN Radiochemicals, Irvine, CA) was also immunoprecipitated from methionine-free RPMI $+20 \%$ dialyzed FCS using identical procedures as for the media, and was used as a radiolabeled marker in conjunction with a prestained low molecular ladder of standards (Bio-Rad Laboratories, South Richmond, CA). The resulting gel was processed with an autoradiograph enhancer (Enhance, DuPont-New England Nuclear, Boston, MA), dried, and autoradiographed.

IGF-I assays. Immunoreactivity for the IGF-IA E peptide was determined from monocyte-conditioned media samples by radioimmunoassay (RIA), as described previously (28). This RIA has been shown to be highly specific for the IGF-IA E peptide and not mature IGF-I or IGF-II. Levels of immunoreactive IGF-I were determined by a specific RIA using anti-IGF-I antiserum from the National Hormone and Pituitary Program.

\section{Results}

Preliminary experiments employing PCR showed that human monocytes can be stimulated by AGE-modified BSA to express mRNA for IGF-I. As shown in Fig. 1, IGF-I transcripts were readily detected from monocytes that had been treated with $150 \mu \mathrm{g} / \mathrm{ml}$ endotoxin-free AGE-BSA for $24 \mathrm{~h}$. However, treatment of monocytes with an equal amount of unmodified BSA, in the presence or absence of $50 \mathrm{U} / \mathrm{ml}(\mathrm{IFN}-\tau)$ failed to do so, indicating that IGF-I expression was a specific response to AGE-modified BSA. IGF-I mRNA levels were greatly reduced in monocytes treated simultaneously with AGE-BSA and IFN$\gamma$. In addition, LPS, a potent inducer of multiple monocyte gene expression, failed to induce IGF-I mRNA at a concentration of $1 \mu \mathrm{g} / \mathrm{ml}$. The DNA product generated in these studies had a predicted length of 268 bp of the IGF-I amplification product. The primers were chosen for the exon sequence separated by the third intron of the IGF-I gene; therefore, the observed band could only have originated from spliced mRNA and not from genomic DNA.

To ensure that the DNA PCR product generated using IGF-I primers originated from IGF-I mRNA, the isolated fragment was digested with the restriction enzymes Bam $\mathrm{HI}$ and Dra I, both of which are specific six basepair cutters. After amplification, isolation and digestion of the full length fragment with the respective restriction enzymes, individual fragment sizes were assessed by gel electrophoresis, which yielded fragments precisely of the expected sizes (data not shown).

Characterization of the human IGF-I gene has shown that the gene extends over at least $45 \mathrm{~kb}$ and contains five exons interrupted by four introns (23). At least two IGF-I mRNAs are generated by alternative processing of the primary gene transcript. The DNA sequence of exons 1 through 4 encodes the IGF-IB mRNA resulting in a 195-amino acid precursor, while alternative splicing of exons $1,2,3$ and 5 produces IGFIA mRNA encoding a 153-residue peptide. The primer pair used in this study was specific for IGF-IA mRNA. The same cDNA was probed with primers specific for the IGF-IB transcript, however no IGF-IB specific band could be detected (data not shown).

The effect of different AGE-BSA concentrations (0-250 $\mu \mathrm{g} / \mathrm{ml}$ ) on the induction of IGF-IA mRNA was investigated. Induction of IGF-IA mRNA was dependent on the amount of AGE-BSA added (Fig. 2). Addition of $1 \mu \mathrm{g} / \mathrm{ml}$ and $10 \mu \mathrm{g} / \mathrm{ml}$ AGE-BSA to monocytes only produced background IGF-IA

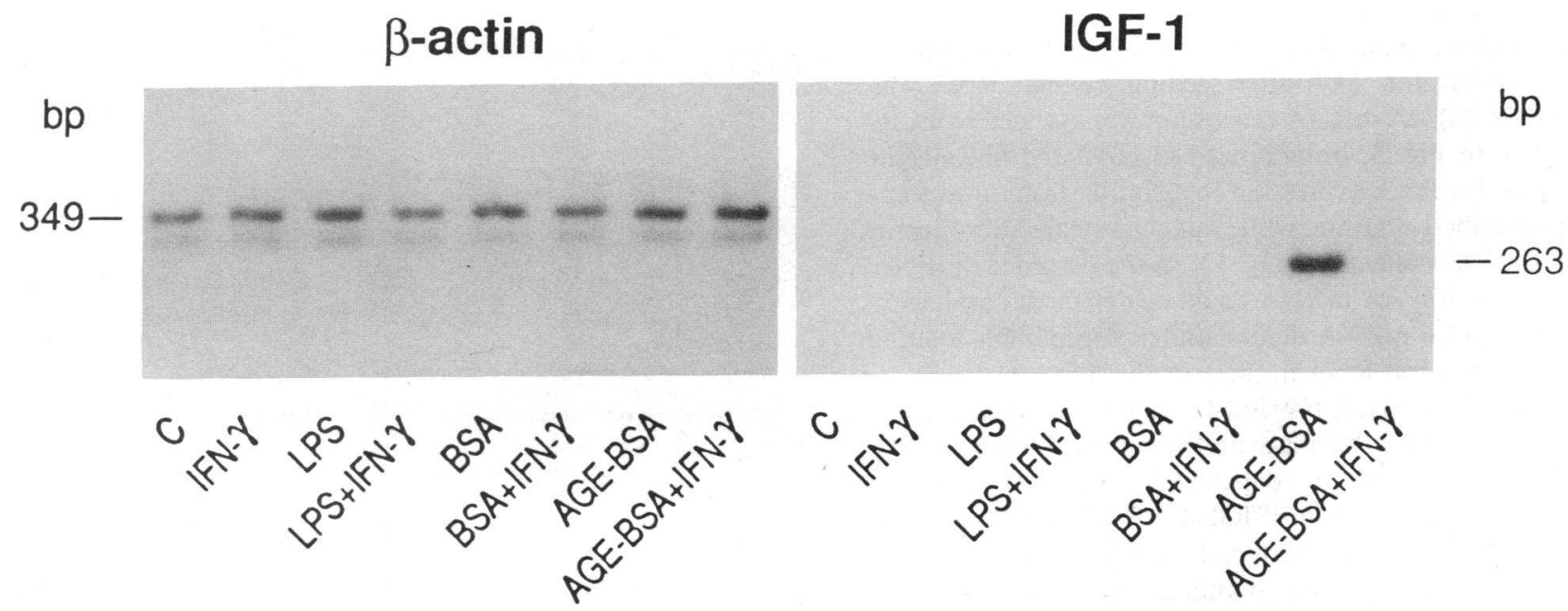

Figure 1. Detection of IGF-IA mRNA in AGE-BSA-treated human monocytes. Cells were incubated with IFN- $\tau$ ( $50 \mathrm{U} / \mathrm{ml})($ lane 2$)$, LPS (1 $\mu \mathrm{g} / \mathrm{ml})$ (lane 3), LPS $(1 \mu \mathrm{g} / \mathrm{ml})$ and IFN- $\tau(50 \mathrm{U} / \mathrm{ml})($ lane 4$)$, BSA $(150 \mu \mathrm{g} / \mathrm{ml})($ lane 5$)$, BSA $(150 \mu \mathrm{g} / \mathrm{ml})$ and IFN- $\tau(50 \mathrm{U} / \mathrm{ml})($ lane 6$)$, AGE-BSA $(150 \mu \mathrm{g} / \mathrm{ml})$ (lane 7), AGE-BSA $(150 \mu \mathrm{g} / \mathrm{ml})$ and IFN- $\tau(50 \mathrm{U} / \mathrm{ml})$ (lane 8$)$, or medium alone for $24 \mathrm{~h}$ (lane 1$)$ and total RNA was extracted. $1 \mu \mathrm{g}$ RNA was reverse transcribed in $50 \mu \mathrm{l}$ of reverse transcription mixture. $5 \mu \mathrm{l}$ of this mixture was amplified by PCR in 30 cycles with either $\beta$-actin primers (left panel) or IGF-IA primers (right panel) as described in Methods. Data are representative of four identical experiments. 


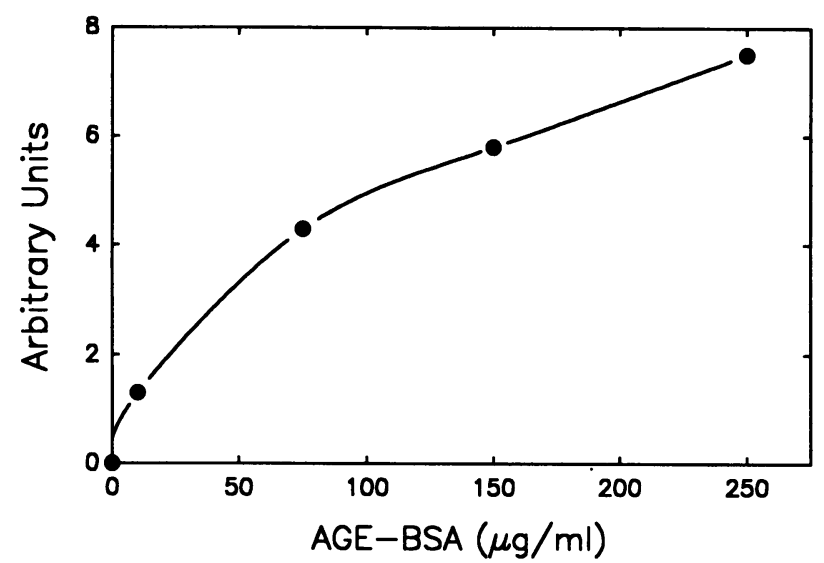

Figure 2. Dose-dependent increase in IGF-IA mRNA induced by AGE-BSA. Human monocytes were treated with increasing amounts of AGE-BSA for $48 \mathrm{~h}$ before total RNA was extracted and $1 \mu \mathrm{g}$ was reverse transcribed. $5 \mu$ l of this cDNA preparation was amplified by PCR for 30 cycles in separate reactions using IGF-IA and $\beta$-actin primers. Products from the PCR reactions were subjected to electrophoresis in $2 \%$ agarose gels containing ethidium bromide and photographed under UV light. The photographic negatives were then scanned in a densitometer and the density of each IGF-I band was normalized to the density of the actin bands and plotted as arbitrary units. Data are representative of four identical experiments.

mRNA levels. However, $75 \mu \mathrm{g} / \mathrm{ml}$ AGE-BSA induced a considerable increase of IGF-IA mRNA of 4.48 times over background levels, whereas 150 and $250 \mu \mathrm{g} / \mathrm{ml}$ AGE-BSA enhanced the response to 5.8- and 7.4-fold, respectively, as assessed by densitometry. Additional experiments showed that the AGE-induced IGF-I mRNA expression depended on the presence of no less than $5 \%$ fetal bovine serum (data not shown).

AGEs accumulate on structural proteins such as collagen and other vessel wall matrix components because of their low physiologic turnover rates. Accordingly, monocyte expression of IGF-IA mRNA in response to an AGE-modified matrix protein was investigated using human blood monocytes seeded onto tissue culture plates precoated with either AGE-modified or native fibronectin. $24 \mathrm{~h}$ after seeding, cellular RNA was extracted and IGF-IA mRNA expression was assessed by PCR. As indicated in Fig. 3, immobilized glycosylated fibronectin induced IGF-I mRNA expression in a similar fashion to soluble AGE-modified albumin, while nonglycosylated fibronectin did not. As observed earlier (Fig. 1), in the presence of IFN- $\tau$ $(50 \mathrm{U} / \mathrm{ml})$ less IGF-IA mRNA could be detected. Parallel expression of $\beta$-actin mRNA demonstrated comparable loading of reverse transcribed RNA in these studies (Fig. 3).

It has been reported previously that AGE-BSA induces both IL- $1 \beta$ and TNF- $\alpha$ message and protein in human monocytes (3). To relate the time-dependent patterns of induction of IL- $1 \beta$ and TNF- $\alpha$ to that of IGF-I mRNA following exposure to AGE-proteins, monocyte induction of all three mRNAs was studied at different time points after exposure to AGEBSA. PCR analysis revealed that IL- $1 \beta$ and TNF- $\alpha$ mRNAs are expressed as early as $2 \mathrm{~h}$ after exposure to AGE-BSA (Fig. 4). After $6 \mathrm{~h}$ of incubation IL- $1 \beta$ mRNA is no longer detectable, whereas low levels of TNF- $\alpha$ mRNA can still be detected for up to $24 \mathrm{~h}$. It is only after $18 \mathrm{~h}$ of incubation with AGE-BSA however, that IGF-I mRNA levels become pronounced, peak-

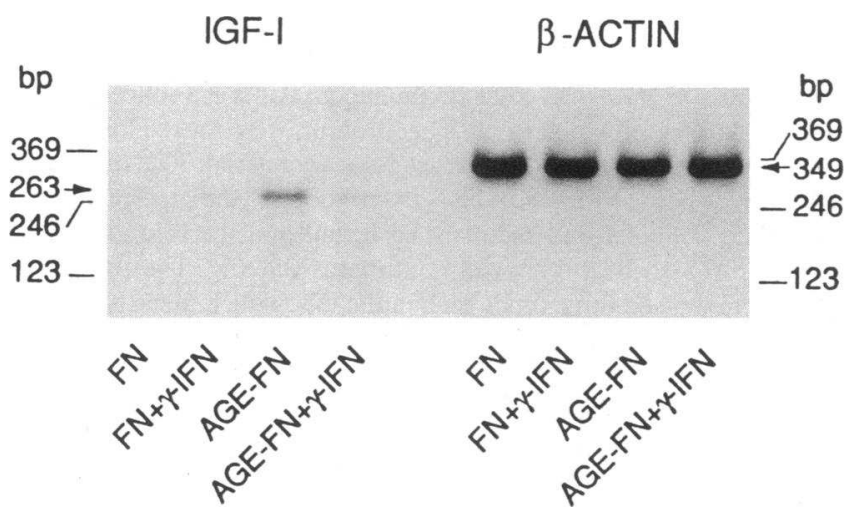

Figure 3. Induction of IGF-IA mRNA in human monocytes seeded onto immobilized AGE-modified fibronectin. Human monocytes were seeded in the presence or absence of IFN- $\tau(50 \mathrm{U} / \mathrm{ml})$ onto tissue culture plates, coated with a unmodified or AGE-modified fibronectin solution at a concentration of $10 \mu \mathrm{g} / \mathrm{ml}$. After $24 \mathrm{~h}$ the cells were lysed in the plates and total RNA was extracted. $1 \mu \mathrm{g}$ of RNA was reverse transcribed and $5 \mu \mathrm{l}$ of each transcription mixture was subjected to PCR. (IGF-IA, 35 cycles; $\beta$-actin 30 cycles). Data are representative of three identical experiments.

ing at $48 \mathrm{~h}$. Equal loading of reverse transcribed RNA was confirmed using $\beta$-actin primers.

To examine the possibility that induction of IGF-I mRNA is secondary to either of the earlier expressed mediators, dependence of IGF-I mRNA expression on IL- $1 \beta$ and TNF- $\alpha$ was tested. As shown in Fig. 5, treatment of monocytes for $24 \mathrm{~h}$ with AGE-BSA in the presence of anti-IL- $1 \beta$ antibody prevented IGF-I mRNA expression, whereas similar monocyte

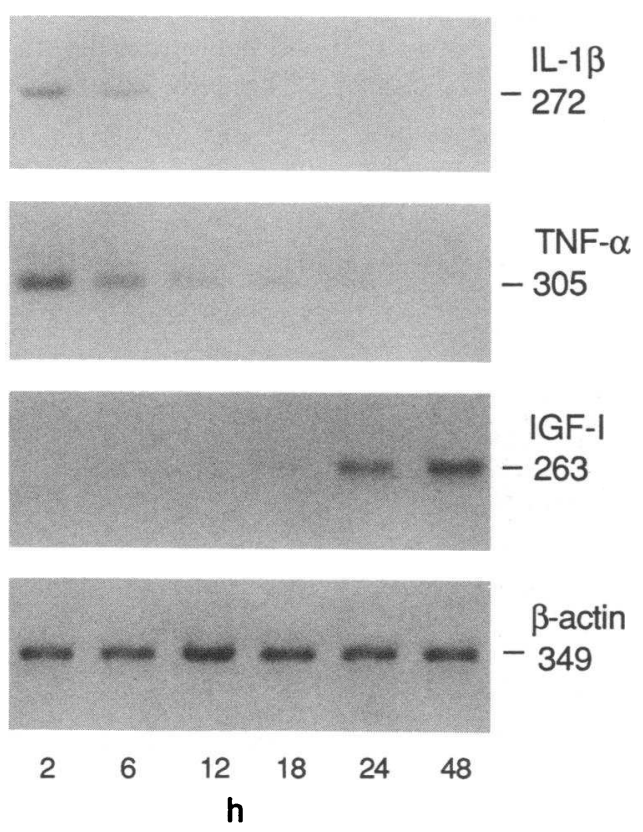

Figure 4. Time course of cytokine induction in AGE-BSA-treated monocytes. Human monocytes were treated with AGE-BSA ( 150 $\mu \mathrm{g} / \mathrm{ml}$ ) for the times indicated and total RNA was extracted. $1 \mu \mathrm{g}$ RNA was reverse-transcribed and $5 \mu l$ of the transcription mixture was subjected to PCR. (IGF-IA and $\beta$-actin, 30 cycles; IL- $1 \beta$ and TNF- $\alpha, 25$ cycles). Data are representative of three identical experiments. 


\section{$\beta$-actin}

\section{IGF-I}

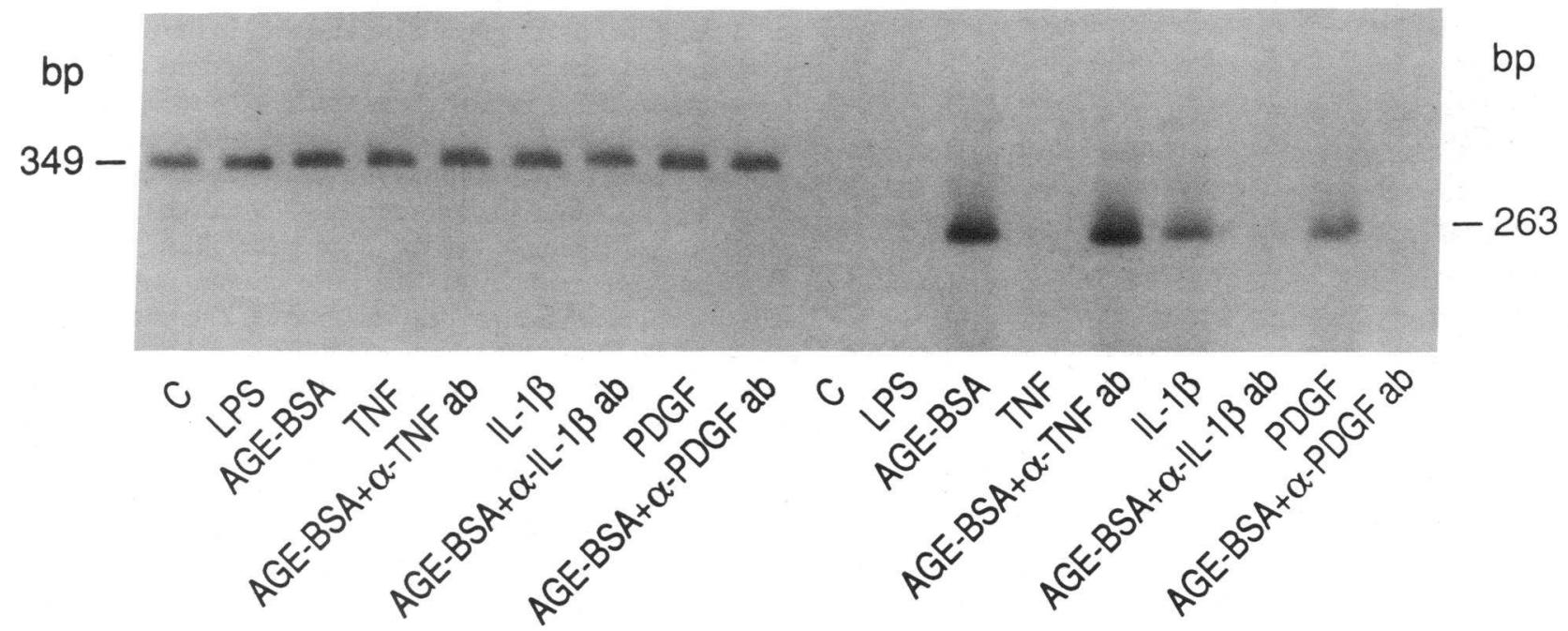

Figure 5. Inhibition of AGE-induced IGF-IA mRNA in human monocytes by anti-IL-1 $\beta$ and anti-PDGF antibodies. Human monocytes were incubated with $150 \mu \mathrm{g} / \mathrm{ml}$ AGE-BSA, $1 \mu \mathrm{g} / \mathrm{ml} \mathrm{LPS}, 150 \mu \mathrm{g} / \mathrm{ml} \mathrm{AGE-BSA}$ in the presence of either anti-TNF antibody $(100 \mu \mathrm{g} / \mathrm{ml})$, anti-IL-1 $\beta$ antibody $(100 \mu \mathrm{g} / \mathrm{ml})$, anti-PDGF antibody $(50 \mu \mathrm{g} / \mathrm{ml})$ or with the cytokines directly $(10 \mathrm{pg} / \mathrm{ml}$ human TNF, $1 \mathrm{ng} / \mathrm{ml} \mathrm{IL-1 \beta}$ and PDGF $(2.5$ half-maximal units) for $24 \mathrm{~h}$. Control $(C)$ monocytes were left untreated for $24 \mathrm{~h}$. Total RNA was extracted and $1 \mu \mathrm{g}$ was reverse transcribed. 5 $\mu \mathrm{l}$ of the reverse transcription mixture was amplified by PCR. ( $\beta$-actin, 30 cycles; IGF-IA, 30 cycles.) Data are representative of three identical experiments.

treatment in the presence of anti-TNF- $\alpha$ antibody had no effect, suggesting that induction of IGF-I mRNA is partly mediated via AGE-induced IL-1 $\beta$.

We have recently reported that AGE-stimulated monocytes also release PDGF (4). Because PDGF is a known mediator of IGF-I mRNA, monocytes were incubated with AGE-BSA in the presence of anti-platelet PDGF antibody. Under those conditions no IGF-I mRNA was produced, indicating that it may also be regulated via AGE-mediated PDGF secretion. To further substantiate these findings, human TNF- $\alpha$, IL- $1 \beta$, and PDGF were added to monocytes directly. As shown in Fig. 5, the direct addition of either IL- $\beta$ or PDGF led to enhanced IGF-I mRNA expression, while TNF- $\alpha$ did not. This is consistent with the notion that the AGE-stimulated enhancement of IGF-I mRNA levels is mediated via either IL- $1 \beta$ or PDGF.

Recently an AGE-receptor system has been identified on macrophages and monocytes consisting of two binding proteins, one with an $M_{\mathrm{r}}$ of $60 \mathrm{kD}$ and the other of $90 \mathrm{kD}$, and neutralizing polyclonal antibodies have been subsequently developed (8). To determine whether the induction of IGF-IA mRNA by AGE-modified proteins is mediated via this receptor system, monocytes were incubated with AGE-BSA in the presence of either anti-p60 or anti-p90 AGE-receptor antibodies. To allow time for antibody equilibration and maintain constant contact with the recycling AGE-receptors, the cells were pretreated with either antibody $(20 \mu \mathrm{g} / \mathrm{ml})$ for $30 \mathrm{~min}$ at $4^{\circ} \mathrm{C}$ before and hourly afterwards. As indicated in Fig. 6, only a trace amount of IGF-IA mRNA was detectable in monocytes treated simultaneously with AGE-BSA and the anti-p60 antibody or both anti-p60 and anti-p90 in combination, indicating inhibition of IGF-I induction above control levels. Antip90 antibody alone had a much smaller inhibitory effect on the IGF-I response (up to $37 \%$ of control as assessed by densitometric analysis).
Induction of mRNA in response to a stimulus is not always followed by the secretion of the corresponding protein. It was therefore important to determine whether AGE-BSA could in fact induce the secretion of IGF-I protein by human monocytes. Using a rabbit polyclonal anti-IGF-I antibody, the supernatants of monocytes treated for $24 \mathrm{~h}$ with AGE-BSA or with zymosan A (a yeast protein-carbohydrate complex, used as a positive control due to its ability to nonspecifically induce macrophages to produce IGF-I) were immunoprecipitated. An

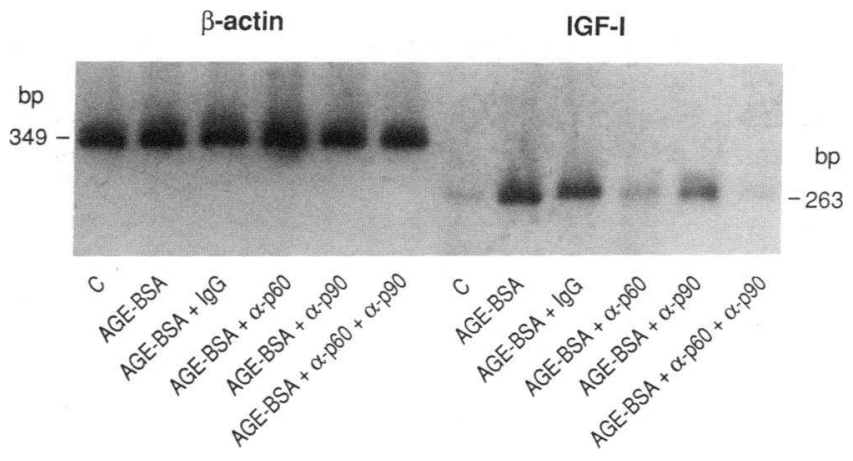

Figure 6. Effect of treatment of monocytes with AGE-BSA in the presence of anti-p60 and anti-p90 receptor antibodies. Human monocytes were treated with $150 \mu \mathrm{g} / \mathrm{ml}$ AGE-BSA in the presence of $20 \mu \mathrm{g} / \mathrm{ml}$ anti-p60 receptor antibody, anti-p90 antibody or both antibodies simultaneously for $6 \mathrm{~h}$. The cells were washed and further incubated in antibody-free medium for $18 \mathrm{~h}$ after which total RNA was extracted. As controls, cells were either left untreated, treated with AGE-BSA $(150 \mu \mathrm{g} / \mathrm{ml})$ alone, or $20 \mu \mathrm{g} / \mathrm{ml}$ chicken IgG was added in the presence of AGE-BSA. $1 \mu \mathrm{g}$ RNA was reverse-transcribed and $5 \mu \mathrm{l}$ of the reverse transcription mixture was added to the PCR reaction. PCR conditions: 30 cycles with $55^{\circ} \mathrm{C}$ annealing temperature for $\beta$-actin or 35 cycles for IGF-I. 


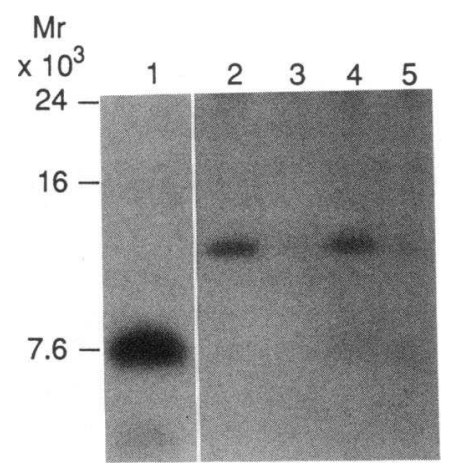

Figure 7. Autoradiography of immunoprecipitated IGF-I from AGE-stimulated monocytes. Monocytes were incubated with zymosan A ( 150 $\mu \mathrm{g} / \mathrm{ml}$ ) (lane 2), left untreated (lane 3), AGE-BSA ( $150 \mu \mathrm{g} /$ $\mathrm{ml})$ (lane 4) or BSA (150 $\mu \mathrm{g}$ / $\mathrm{ml}$ ) (lane 5 ) for $24 \mathrm{~h}$ in the presence of $\left[{ }^{35} \mathrm{~S}\right]$-methionine. Supernatants were harvested and IGF-I was immunoprecipitated with a rabbit polyclonal anti-human IGF-I antibody as described in Methods and electrophoresed on a gradient SDS-PAGE $(10-18 \%)$. Iodinated recombinant liver IGF-I $(7.6 \mathrm{kD})$ was used as a positive control (lane 1). Representative of two identical experiments.

autoradiograph of SDS-PAGE from these cell cultures showed the precipitation of a single protein of $13-14 \mathrm{kD}$ (Fig. 7, lanes 2 and 4$)$, which is several kilodaltons larger than the recombinant hepatocyte IGF-I (7.6 kD) (Fig. 7, lane 1). Only background levels of IGF-I-like protein could be detected in supernatants of either untreated or native BSA-treated cells.

Recently, Conover et al. (28) have described the secretion by growth hormone-treated fibroblasts of an IGF-I prohormone with a molecular mass of $13-19 \mathrm{kD}$. The nucleotide sequence of the cDNA of this molecule has indicated that the IGF-IA prohormone is derived from a region which extends an additional 35 amino acids beyond the carboxyterminal end of the mature IGF-I molecule. This has been termed E peptide. Because the IGF-I-like molecule secreted by AGE-stimulated monocytes and the IGF-I prohormone secreted by fibroblasts appeared similar in size, we questioned whether the species of IGF-I secreted by monocytes corresponds to the IGF-IA prohormone. Supernatants derived from either unmodified BSAor AGE-BSA-stimulated monocytes were tested by RIA for immunoreactivity with an antiserum directed against a synthetic segment of the predicted $E$ peptide region which is unique to the IGF-IA prohormone (28), as well as with an antibody that recognizes both, the prohormone as well as the mature IGF-I peptide. As shown in Table I, both antibodies recognized severalfold greater amounts of IGF-I in the super-

Table I. Quantitation of AGE-induced IGF-I Prohormone Production

\begin{tabular}{lcc}
\hline \multicolumn{1}{c}{ Sample } & Pro-IGF-I E region & IGF-I \\
\hline & \multicolumn{2}{c}{$p m o l / 15 \mathrm{ml}$} \\
RPMI & $0.00 \pm 0.05$ & $0.00 \pm 0.01$ \\
BSA & $0.16 \pm 0.08$ & $0.10 \pm 0.02$ \\
AGE-BSA & $0.32 \pm 0.13$ & $0.39 \pm 0.05$ \\
\hline
\end{tabular}

Human monocytes were incubated with either BSA $(150 \mu \mathrm{g} / \mathrm{ml})$ or AGE-BSA $(150 \mu \mathrm{g} / \mathrm{ml})$ for $4 \mathrm{~h}$ in medium containing $20 \% \mathrm{FBS}$. The medium was then replaced with serum-free medium and the supernatants were harvested after $\mathbf{4 8} \mathrm{h}$. Immunoreactivity for the E-peptide of the prohormone and for the mature IGF-I peptide $(7.5 \mathrm{kD})$ was determined by RIA as described in Methods. Serum-free medium, which is devoid of IGF-I, served as a negative control. natants of AGE-BSA treated monocytes than in the supernatants of native BSA-treated monocytes. In that the antibody to the mature IGF-I peptide recognizes both, the prohormone and the mature hormone, while the antibody to the propeptide recognizes only the prohormone, and the amounts of mature IGF-I and of IGF-I prohormone which were recognized by both antibodies in the AGE-BSA-treated cells were similar $(0.32 \pm 0.13$ and $0.39 \pm 0.05 \mathrm{pmol} / 15 \mathrm{ml})$, it can be concluded that a large portion of the immunoreactivity is due to the prohormone. Supernatants derived from either BSA- or AGEBSA-stimulated monocytes were also immunoprecipitated with the antiserum against the prohormone. The immunoprecipitation confirmed the presence of IGF-IA prohormone produced by AGE-stimulated monocytes, with minimal amounts of IGF-IA prohormone produced by control BSA-treated monocytes (data not shown).

It has been shown that some IGF-I secreting cells also secrete IGF-I binding proteins (12-14). To test whether human monocytes secrete their own binding proteins under these conditions, supernatants from BSA and AGE-BSA treated monocytes were assayed for IGF-I binding proteins by ligand blotting (29). No binding proteins could be detected however (data not shown).

\section{Discussion}

Monocytes and macrophages play an important role in connective tissue homeostasis and normal remodeling. A recently proposed mechanism by which these cells can selectively identify, internalize, and remove senescent proteins operates via a monocyte/macrophage receptor system specific for the AGEmoieties that form on proteins as tissues are exposed to ambient glucose $(30,31)$. Receptor-mediated uptake of AGE-proteins initiates a sequence of cytokine-mediated processes known to promote tissue remodeling (3) by recruiting cells of mesenchymal origin and initiating cellular proliferation, new matrix protein synthesis and/or release of extracellular proteases (5). In addition, we have demonstrated that AGE-modified substrates induce monocytes to secrete PDGF (4), shown to act as a "competence" factor by priming cells of mesenchymal origin to enter mitosis. We therefore pursued our search for the terminal mediator responsible for cell proliferation and tissue remodeling which is induced by AGE-proteins via the AGE-receptor-cytokine-growth factor cascade.

IGF-I, among the known growth promoting peptides and according to the "dual control" concept of cell proliferation, is one of the "progression" factors which prompt "competence" factor-primed fibroblasts to proceed through $G_{1}$ phase (9). In this context, we inquired whether IGF-I is involved in the AGE-mediated tissue remodeling network of responses likely to participate in normal tissue remodeling. An AGE-protein specific increase in IGF-I mRNA was observed in human monocytes. Induction of IGF-IA mRNA was AGE dose-dependent, and was equally well elicited in response to soluble AGE-BSA as it was to insoluble AGE-fibronectin. This is of particular significance in vivo, because most structural tissue components, e.g., collagen and basement membrane proteins, by virtue of their low physiologic turnover rates tend to accumulate AGEs $(5,6)$.

Recently two AGE-specific receptor proteins were purified from rat liver membranes ( $p 60$ and $p 90$ ) against each of which 
specific polyclonal antibodies were raised (8). By using these antibodies, it was established that the induction of IGF-IA mRNA by glucose-modified proteins is mediated specifically via the AGE-receptor system. No IGF-IA mRNA induction was observed in the presence of anti-p60 antibody, whereas the anti-p90 antibody only inhibited the response partially. This is consistent with the previously expressed notion that, of the two receptor subunits, the p60 may be the one more capable of immobilizing AGE-ligands by itself as compared to the p90 (8). Although the subsequent events following the receptor-ligand coupling need be further elucidated, the present data point to the AGE-receptor system present at the cell surface as the primary initiator of a complex process that leads eventually to IGF-I secretion.

The time-dependent course of IGF-IA mRNA increase revealed strong expression after $48 \mathrm{~h}$ of exposure to AGEs, a pattern distinctly different from that observed for the AGEtriggered increases in IL- $1 \beta$ and TNF- $\alpha$ mRNA. Both of these messages appeared earlier (after $2 \mathrm{~h}$ ) and disappeared within $12 \mathrm{~h}$ of cell exposure to AGE-BSA ligand. This difference in latency caused us to speculate that IGF-I mRNA expression might occur indirectly, mediated by either IL-1 $\beta$ or TNF- $\alpha$. The presence of anti-IL- $1 \beta$ antibody prevented the AGE-stimulated increase in IGF-I mRNA levels, while anti-TNF- $\alpha$ antibody did not, suggesting that IL- $1 \beta$ may act as an intermediary factor in this system. Consistent with this, adding IL- $1 \beta$ alone to the cells reproduced the increase in IGF-I mRNA.

Alternative pathways however seem to exist, especially inasmuch as IGF-I is inducible in other cells, such as fibroblasts or human thyroid follicular cells by growth hormone (GH) and thyroid stimulating hormone ( TSH $)(28,32)$. Addition of $\mathrm{GH}$ to monocytes failed to elicit an increase in IGF-IA mRNA (data not shown); however, the addition of platelet-derived growth factor (PDGF) promptly elicited a significant response. This novel observation may be of particular interest given the fact that AGE-modified proteins can stimulate human monocytes to secrete PDGF (4), a factor widely implicated in the mesenchymal proliferative responses typical of atherosclerosis $(33,34)$. Anti-PDGF antibody suppressed the AGE-triggered increase in IGF-IA mRNA, suggesting that PDGF secretion may serve as another intermediate step in this network. IL-1 has been previously shown to induce other mediators, such as PDGF which in turn induces "early genes" of cell cycle replication such as c-myc and c-fos (35). In this case, the AGE may initiate the chain of events, via IL-1 and PDGF terminates them with the eventual synthesis and elaboration of intact IGFI protein in the form of IGF-I prohormone. In this context, in separate studies the presence of anti-IL-1 antibody did not hinder PDGF-mediated IGF-IA synthesis, while in the reverse experiment the addition of anti-PDGF antibody inhibits the production of IGF-IA via IL-1 (unpublished data).

This is of particular relevance since monocyte activation, frequently accompanied by the induction of several genes, does not always lead to the secretion of the corresponding active protein. Several forms of IGF-I have been described, including a liver-derived IGF-I with a molecular mass of $7.6 \mathrm{kD}$ (11), tissue-type forms of IGF-I from fibroblasts $(21.5 \mathrm{kD})(15,16)$ and Sertoli cells (25 kD) (36), and an IGF-I secreted from activated human alveolar macrophages ( $25 \mathrm{kD})$ (17). Immunoprecipitation of supernatants obtained from AGE-treated monocytes supernatants yielded an IGF-I protein of $14 \mathrm{kD}$. A similar size IGF-IA prohormone has been shown to be secreted by fibroblasts in response to $\mathrm{GH}$ (28). By employing both an RIA and immunoprecipitation using an antibody that detects the IGF-IA prohormone, it was confirmed that a molecule identical in size to the IGF-I prohormone was secreted by AGE-stimulated monocytes. In addition, when the supernate was immunoprecipitated using antibody directed at the mature IGF-I protein, only a $14-\mathrm{kD}$ product could be identified in subsequent gel electrophoresis and no $7.6-\mathrm{kD}$ product. These data provided further evidence that it is the intact prohormone form of IGF-IA which is secreted alone, since any cleavage during the processing of the molecule would yield in part 7.6 $\mathrm{kD}$ IGF-I plus the E peptide fragment (28).

Although the physiological role of the IGF-I prohormone is still not entirely clear, Conover et al. (28) have proposed a discrete biological function for it in the regulation of cellular growth, given its production by certain tissue cells such as human fibroblasts. The findings presented here may lend support to this hypothesis in a different cell system, that of the monocyte/macrophages. In addition, they introduce a novel in vivo mediator of IGF-I prohormone: the glucose-modified proteins generated spontaneously in tissues. Although other IGF-I producing cells (e.g., endothelial cells, mesangial cells, and fibroblasts have also been shown to contain receptors for AGEs [37-39]), there is no evidence thus far to suggest that AGEbinding on these cells results in IGF-IA secretion.

Although AGE-modified proteins and to a far greater extent, LPS have both been shown to stimulate the secretion of potent cytokines such as IL- $1 \beta$, TNF- $\alpha(3,40)$, only AGE-modified proteins lead to IGF-I production. In fact, the addition of LPS to AGE-proteins inhibits the induction of IGF-I in a dosedependent manner (unpublished data). The mechanism of this suppression is not clear, but it may reflect the activity of an inhibitor of IGF-I production. Another possibility is that LPS, through the induction of IL-I receptor antagonist, prevents the autocrine action of IL-1 on the macrophages and the subsequent production of IGF-I. Preliminary work has shown that, in contrast to LPS, AGE-proteins do not induce the synthesis of this inhibitor. Further work is needed to understand this phenomena, however.

The observaltion that AGE-stimulated monocytes are induced to secrete IGF-I, a factor with progression-type properties, substantiates the notion that in vivo forming AGE-proteins might play an important role in normal tissue remodeling. This may take effect through the coordinated secretion of key cytokines and growth factors exerting both competence (e.g., via PDGF) and progression (e.g., via IGF-I) type properties on various target cells of mesenchymal origin. In certain conditions, such as in chronic diabetes and normal aging, where enhanced accumulation of AGE-products has been demonstrated $(5,6,41)$, the abnormal over-production of such growth factors might contribute to progressive tissue disorganization by promoting abnormal cellular proliferation and protein synthesis.

\section{Acknowledgments}

We are grateful for the support of National Institute of Health grants AGO 8245 and AGO 6943 to Dr. Helen Vlassara, and DK-24085 to Dr. Raymond Hintz. Antiserum against IGF-I was donated by Drs. Underwood and Van Wyk of the University of North Carolina and distributed by the National Hormone and Pituitary Program (UBK487). Dr. Martina Kirstein is a fellow of the New York Health Research Council. 


\section{References}

1. Rappolee, D. A., D. Mark, M. J. Banda, and Z. Werb. 1988. Wound macrophages express TGF- $\alpha$ and other growth factors in vivo: analysis by $\mathrm{mRNA}$ phenotyping. Science (Wash. DC). 241:708-712.

2. Leibovich, S. J., and R. Ross. 1975. The role of the macrophage in wound repair. Am. J. Pathol. 78:71-100.

3. Vlassara, H., M. Brownlee, K. R. Manogue, C. A. Dinarello, and A. Pasagian. 1988. Cachectin/TNF and IL-1 induced by glucose-modified proteins: Role in normal tissue remodeling. Science (Wash. DC). 240:1546-1548.

4. Kirstein, M., J. Brett, S. Radoff, S. Ogawa, D. Stern, and H. Vlassara. 1990. Advanced protein glycosylation induces transendothelial human monocyte chemotaxis and secretion of platelet-derived growth factor: role in vascular disease of diabetes and aging. Proc. Natl. Acad. Sci. USA. 87:9010-9014.

5. Brownlee, M., A. Cerami, and H. Vlassara. 1988. Advanced glycosylation endproducts in tissue and the biochemical basis of diabetic complications. $N$. Engl. J. Med. 318:1315-1321.

6. Monnier, V. M., R. R. Kohn, and A. Cerami. 1984. Accelerated age-related browning of human collagen in diabetes mellitus. Proc. Natl. Acad. Sci. USA 81:583-587.

7. Radoff, S., A. Cerami, and H. Vlassara. 1990. Isolation of a surface binding protein for advanced glycosylation endproducts from mouse macrophage-derived cell line RAW 264.7. Diabetes. 39:1510-1518.

8. Yang, Z., Z. Makita, Y. Horii, S. Brunelle, A. Cerami, P. Sehajpal, M Suthanthiran, and H. Vlassara. 1991. Two novel rat liver membrane proteins that bind advanced glycosylation endproducts: Relationship to macrophage receptor for glucose-modified proteins. J. Exp. Med. 174:515-524.

9. Stiles, C. D., G. T. Capone, C. D. Scher, H. N. Antoniades, J. J. Van Wyk, and W. J. Pledger. 1979. Dual control of cell growth by somatomedins and platelet-derived growth factor. Proc. Natl. Acad. Sci. USA. 76:1279-1283.

10. Van Wyk, J. J., and L. E. Underwood. 1978. The somatomedins and their actions. In Biochemical Action of Hormones. Volume 5. G. Litwak, editor. Academic Press, Inc., New York. 101-148.

11. Froesch, E. R., C. Schmid, J. Schwander, and J. A. Zapf. 1985. Actions of insulin-like growth factors. Annu. Rev. Physiol. 47:443-467.

12. Nissley, S. P., and M. M. Rechler. 1985. Insulin-like growth factors: biosynthesis, receptors and IGF-I carrier proteins. In Hormonal Proteins and Peptides. Volume 12. C. Li, editor. Academic Press, Inc. New York. 127-203.

13. Hintz, R. L. 1984. Plasma forms of somatomedin and the binding protein phenomenon. Clin. Endocrinol. Metab. 13:31-42.

14. Baxter, R. C., and J. L. Martin. 1989. Binding proteins for the insulin-like growth factors: structure, regulation and function. Prog. Growth Factor Res. 1:49-68.

15. Clemmons, D. R., and D. S. Shaw. 1986. Purification and biological properties of fibroblast somatomedin. J. Biol. Chem. 261:10293-10298.

16. Clemmons, D. R., and J. J. Van Wyk. 1985. Evidence for a functional role of endogenously produced somatomedin-like peptides in the regulation of DNA synthesis in cultured human fibroblasts and porcine smooth muscle cells. J. Clin. Invest. 75:1914-1918.

17. Rom, W. N., P. Basset, G. A. Fells, T. Nukiwa, B. C. Trapnell, and R. G. Crystal. 1988. Alveolar macrophages release insulin-like growth factor I-Type molecule. J. Clin. Invest. 82:1685-1693.

18. Boyum A. 1968. Isolation of mononuclear cells and granulocytes from human blood. Scand. J. Clin. Lab. Invest. 21 (Suppl. 97):77.

19. Timonen, T., and E. Saksela. 1980. Isolation of human NK cells by density gradient centrifugation. J. Immunol. Methods. 36:285-291.

20. Vlassara, H., M. Brownlee, and A. Cerami. 1985. High-affinity-receptormediated uptake and degradation of glucose-modified proteins: A potential mechanism for the removal of senescent macromolecules. Proc. Natl. Acad. Sci. USA. 82:5588-5592.

20a. Radoff, S., Z. Makita, and H. Vlassara. 1991. Radioreceptor assay for advanced glycosylation end products. Diabetes. 40:1731-1738.

21. Jones, P. A., T. Scott-Burden, and W. Gevers. 1979. Glycoprotein, elastin and collagen secretion by rat smooth muscle cells. Proc. Natl. Acad. Sci. USA. 76:353-357.
22. Lowry, O. H., N. J. Rosebrough, A. L. Farr, and R. J. Randall. 1951. Protein measurement with the folin phenol reagent. J. Biol. Chem. 193:265-275.

23. Rotwein, P., K. M. Pollock, D. K. Didier, and G. G. Krivi. 1986. Organization and Sequence of the human insulin-like growth factor I gene. J. Biol. Chem. 261:4828-4832.

24. Hanokoglu, I., N. Tanese, and E. Fuchs. 1983. Complementary DNA sequence of human cytoplasmic actin. Interspecies divergence of 3, non-coding regions. J. Mol. Biol. 163:673-678.

25. March, C. J., B. Mosley, A. Larsen, D. P. Cerretti, G. Braedt, V. Price, S Gillis, C. S. Henney, S. R. Kronheim, K. Grabstein, et al. 1985. Cloning, sequence and expression of two distinct interleukin-1 complementary DNAs. $\mathrm{Na}$ ture (Lond.). 315:641-647.

26. Wang, A. M., A. A. Creasey, M. B. Ladner, L. S. Lin, J. Strickler, J. N. Van Arsdell, R. Yamamoto, and D. F. Mark. 1985. Molecular cloning of the complementary DNA for human tumor necrosis factor. Science (Wash. DC). 228:149154.

27. Furlanetto, R. W., L. E. Underwood, J. J. Van Wyk, and A. J. D'Ercole. 1977. Estimation of somatomedin $\mathrm{C}$ levels in normals and patients with pituitary disease by radioimmunoassay. J. Clin. Invest. 60:648-657.

28. Conover, C. A., B. K. Baker, and R. L. Hintz. 1989. Cultured human fibroblasts secrete insulin-like growth factor IA prohormone. J. Clin. Endocrinol. Metab. 69:25-30.

29. Hossenlopp, P., D. Seurin, B. Segovia-Quinson, S. Hardouin, and M Binoux. 1986. Analysis of serum insulin-like growth factor binding proteins using Western blotting: use of the method for titration of the binding proteins and competitive binding studies. Anal. Biochem. 154:138-143.

30. Vlassara, H., M. Brownlee, and A. Cerami. 1986. Novel macrophage receptor for glucose-modified proteins is distinct from previously described scavenger receptors. J. Exp. Med. 164:1301-1309.

31. Vlassara, H., L. Moldawer, and B. Chan. 1989. Macrophage/monocyte receptor for nonenzymatic glycosylated proteins is upregulated by cachectin/tumor necrosis factors. J. Clin. Invest. 84:1813-1820.

32. Tode, B., M. Serio, C. M. Rotella, G. Galli, F. Franceschelli, A. Tanini, and R. Toccafondi. 1989. Insulin-like growth factor-I: Autocrine secretion by human thyroid follicular cells in primary culture. J. Clin. Endocrinol. Metab. 69:639-647.

33. Ross, R. 1986. The pathogenesis of atherosclerosis-an update. N. Engl. J. Med. 314:488-500.

34. Ross, R., J. Masuda, E. W. Raines, A. M. Gown, S. Katsuda, M. Sasahara, L. T. Malden, H. Masuko, and H. Sato. 1990. Localization of PDGF-B protein in macrophages in all phases of atherogenesis. Science (Wash. DC). 248:1009 1012.

35. Greenberg, M., and E. B. Ziff. 1984. Stimulation of 3T3 cells induces transcription of the c-fos proto-oncogene. Nature (Lond.). 311:433-437.

36. Smith, E. P., M. E. Svoboda, J. J. Van Wyk, A. L. Kierzenbaum, and L. L. Tres. 1987. Partial characterization of a somatomedin-like peptide from the medium of cultured rat sertoli cells. Endocrinology. 120:186-193.

37. Esposito, C., D. Stern, H. Gerlach, and H. Vlassara. 1989. Endothelial receptor-mediated binding of glucose-modified albumin is associated with increased monolayer permeability and modulation of cell surface coagulant properties. J. Exp. Med. 170:1387-1407.

38. Skolnik, E. Y., Z. Yang, Z. Makita, S. Radoff, M. Kirstein, H. Vlassara. 1990. Human and rat mesangial cell receptors for glucose-modified proteins: Potential role in kidney tissue remodelling and diabetic nephropathy. $J$. Exp. Med. 174:931-939.

39. Kirstein, M., S. van Deventer, H. Vlassara. 1990. Advanced glycosylation endproduct (AGE) binding to its specific receptor on human fibroblasts stimulates increase in EGF and EGF receptor mRNAs: role in tissue remodeling. $J$. Cell Biochem. Suppl. 14E:O224.

40. Sherry, B., and A. Cerami. 1988. Cachectin/tumor necrosis factor exerts endocrine, paracrine, and autocrine control of inflammatory responses. $J$. Cell Biol. 107:1269-1277.

41. Monnier, V. M., V. Vishwanath, K. E. Frank, C. A. Elmets, P. Dauchot, and R. R. Kohn. 1986. Relation between complications of type 1 diabetes mellitus and collagen-linked fluorescence. N. Engl. J. Med. 314:403-408. 